\title{
Factors Affecting Adoption of Emergency Evacuation Strategies in High-Rise Office Buildings
}

\author{
Farid Wajdi Akashah" ${ }^{1,2 *}$, Timothy Kurannen Baaki ${ }^{3}$, Muhammad Firdaus Anuar², Nur \\ Farhana Azmi ${ }^{2}$, Zahiriah Yahya ${ }^{4}$ \\ ${ }^{I}$ Centre for Building, Construction \& Tropical Architecture (BuCTA), Faculty of Built Environment, \\ University of Malaya 50603 Kuala Lumpur, Malaysia \\ ${ }^{2}$ Department of Building Surveying, Faculty of Built Environment, University of Malaya, 50603 Kuala \\ Lumpur \\ ${ }^{3}$ School of Civil Engineering and Built Environment, Liverpool John Moores University, L3 3AF, \\ Liverpool, United Kingdom \\ ${ }^{4}$ Department of Real Estate, Faculty of Built Environment, University of Malaya, 50603 Kuala Lumpur \\ I*faridakashah@um.edu.my
}

Published: $31^{\text {st }}$ December 2020

This study examined the evacuation strategies employed in high-rise buildings as well as determined factors influencing decision making in employing evacuation strategies in four selected high-rise buildings in Kuala Lumpur, Malaysia. Through a case study evaluation involving interviews with facility/building managers, walk through observations of the case studies and analyses of evacuation exercise reports, the study found that total evacuation was the most practiced evacuation strategy with occasional phased evacuation at one of the case studies. The study identified reliable emergency response, building characteristics/fire safety features, and evacuation exercise as the most important factors influencing decision making in employing evacuation strategies. Occupant characteristics was found to be the least important factor. The argument is that, efficient emergency response, passive and active fire safety systems, and evacuation exercise routines mean that challenges posed by the characteristics of occupants could be overcome. This paper gives new insights on factors influencing decision making in employing suitable evacuation strategies. This would benefit stakeholders e.g. building owners, facility managers, health and safety managers when drafting business continuity plans.

Keywords: business continuity management, disaster management, evacuation drills, evacuation strategies, fire safety performance 


\section{INTRODUCTION}

The 9-11 attacks on the World Trade Centre brought about a great deal of attention to the safety of high-rise building users. Such focus continues to raise questions regarding evacuation scenarios for emergency situations in high-rise buildings (Ariff, 2003; Ronchi and Nilsson, 2013) from low-cost housings (Akashah et al., 2017; Nizam Husin et al, 2018) to offices (Lin et al., 2010; Proulx and Bénichou, 2010). The National Fire Protection Association (2012) has defined high-rise buildings as "buildings greater than 75 feet (approximately $23 \mathrm{~m}$ ) in height where the building height is measured from the lowest level of fire department vehicle access to the floor of the highest occupiable story". Buildings more than 50 meters in height need to have fire safety installations such as sprinkler systems, smoke pressurisation system and smoke management systems because high-rise buildings present a unique challenge to emergencies. While others have argued that the risk of fire posed by the complexity of high-rise buildings is continually being addressed by incorporating specific fire protection features into the design of high-rise buildings (Akashah et al., 2017; Nimlyat et al., 2017), Chow (2004) notes that fires for instance in high-rise buildings are more difficult to extinguish as direct rescue is not possible from the building exterior. Also, longer time is required for evacuation in high-rise buildings in the event of accidental fires (Chow, 2006). This, according to Chow (2012), is due to high occupant and fire loading and the increasing complexity of high-rise buildings. Various evacuation strategies have been developed for high-rise buildings (Ronchi and Nilsson, 2014). For instance, phased evacuation strategy in high-rise buildings with large populations is preferable since it is impractical to rely on stair capacity for simultaneous egress (Bukowski, 2007). Over the last 3 decades, Malaysia has witnessed rapid development with a proliferation of iconic high rise buildings. Malaysia is currently home to the tallest twin towers in the world-14th tallest structure in the world, with others under construction like The Exchange 106 and the 'mega-tall' Warisan Merdeka, a 118-storey office building (CBUTH, 2018). Studies on fire evacuation in high-rise buildings have concentrated mostly on evacuation modelling and egress components, and human characteristics and behaviour during evacuations (Ronchi and Nilsson, 2013; Zhang, 2017; Huo et al., 2016; Qu et al., 2014; Huang et al., 2014; Ronchi et al.,
2014). A literature review by Ronchi and Nilsson (2013) on factors affecting performance of people during fire evacuations in high-rise buildings, evacuation procedures and strategies for high-rise buildings, and capabilities of evacuation models found that effectiveness of egress components were strongly affected by the building use and its population, while stairs and elevators were found to be the traditional means of escape, with alternative means of escape such as skybridges and helicopters. The study also found that suitability of egress models depends on their flexibility in accommodating different egress components and complicated behavioural processes. Suitable evacuation strategies need to be employed together with the involvement of emergency reliable response services, considering also the characteristics of building occupants and the building itself. This study aims to evaluate emergency evacuation scenarios in selected highrise office buildings in Malaysia with specific focus on identifying evacuation strategies of highrise buildings as well as the factors considered in the decision making for adopting an evacuation strategy. This research will benefit responsible persons such as asset owners, facilities managers, health and safety managers and emergency response teams to develop, re-assess or improve their emergency response plan and evacuation strategy.

\section{FIRE SAFETY COMPONENTS AND EVACUATION STRATEGIES FOR HIGH RISE BUILDINGS}

\subsection{Fire Safety Components in High-rise Buildings}

\subsubsection{Staircases}

The traditional means of escape is staircase. People would automatically make use of the staircase in the event of a fire or an emergency. However, it is difficult for high-rise building users to evacuate through hundreds of flights of staircase during an emergency. Different persons have different physical characteristics. Therefore, some tall buildings use lifts in place of staircases for evacuation. The evacuation time by using staircase evacuation strategy is longer than using lift evacuation strategy. This is because people might panic and cause long disorganized queuing at the exits during emergency egress (Aloi and Rogers, 2002). Furthermore, the direction of the evacuation routes of occupants is opposite to the direction of fire fighters, which can easily cause congestion at the staircase exits (Chow, 2004). 


\subsubsection{Evacuation Lifts}

Traditionally, building users are advised not to use lifts during fire emergencies (Nilsson and Jönsson, 2011). However, the lift evacuation method has been accepted by society today as it is a quicker means to effectively evacuate tall buildings (Chen, Wang and Fang, 2016; Ronchi and Nilsson, 2013), however, they must be specifically designed and designated for the purpose of emergency evacuation (Nguyen, Mendis and Fernando, 2019). This is because lift evacuation strategy can reduce evacuation time, decrease occupant fatigue caused by stairs during evacuation, and ease evacuation of people with disabilities (Butler, Kuligowski, Furman and Peacock, 2017). The decision making for the use of lifts to evacuate is based on the threat to life (Australian Building Codes Board, 2013). Normally shuttle lifts can be used as emergency lifts (Wong et al., 2005). Double deck lifts are permitted for use up to 80 levels from the terminal lobby (Barney, 2002). For example, the 88 -storey height Petronas Twin Towers has 29 double deck lifts for each tower. Enhanced lifts are a potential option and result in $40 \%$ decrease in overall evacuation times (Lane and Lamont, 2005).

\subsubsection{Sky-bridge}

Another means of escape for high-rise buildings is the sky-bridge. The sky-bridge act as a horizontal evacuation means between towers (Ronchi and Nilsson, 2013). The sky-bridge concept is to evacuate occupants at a level other than ground floor if the vertical evacuation route to the ground floor of one tower in an emergency is cut off (Wood, 2003). During the re-design competition proposals for the World Trade Centre, five out of the seven designs proposed the inclusion of a sky-bridge (Wood and Oldfield, 2007). One of the famous skyscrapers that use skybridge as means of escape is Petronas Twin Towers in Malaysia (Ronchi and Nilsson, 2013). Vertical towers and horizontal sky-bridge make the evacuation routes into more patterns (Wood and Oldfield, 2007). The travel distance for vertical evacuation can be reduced when occupants use the sky-bridge, thus improving the effectiveness of the evacuation.

\subsubsection{Refuge Floors}

Refuge floor is a special floor designated for safely holding occupants in a high-rise building. Soltanzadeh, Alaghmandan and Soltanzadeh (2018) notes that, for high-rise buildings in particular, refuge floors have become a necessary space. The function of refuge floor is to act as a temporary evacuation hold for occupants (Cheng et al., 2010). It is the last option in the event of an emergency, after the staircases are blocked off and the evacuation lifts have technical problems. It also is a safe place for people with disabilities to wait for rescue (Bukowski, 2009). A study by Soltanzadeh, Alaghmandan and Soltanzadeh (2018) found that having only a floor as refuge area in combination with 3 staircases and 6 evacuation lifts allowed for the most optimal evacuation, resulting in $25 \%$ more people taken out of a 40-storey building compared to having multiple floors as refuge areas. Refuge floors need to have adequate lighting and be free from obstruction (Wong et al., 2005). They should be designed with full fire resistance and should have sufficient ventilation to prevent the logging of smoke (Wei et al., 2002; Walls, 2001).

\subsection{Evacuation Strategies of High-rise Buildings}

\subsubsection{Total Building Evacuation}

Total evacuation or full evacuation involves the evacuation of all occupants from the building at the same time (Aloi and Rogers, 2002). Normally, total evacuation strategy is applied to low rise buildings. This is because the time for evacuation depends on the number and types of occupants, the building usage, the height of building, and the number of exits available (Metropolitan Fire \& Emergency Services Board, 2010). It might not be suitable to adopt total evacuation strategy to highrise buildings due to the extreme height of the structures and also do not have only large number of occupants but high occupant density (Proulx, 2002; Nguyen, Mendis and Fernando, 2019).

\subsubsection{Phased Evacuation}

Phased evacuation strategies are used in high-rise buildings especially super high-rise buildings (Chow et al., 2013). Phased evacuation strategies involve evacuation of the fire floor and one or two floors above and below the fire floors (Proulx, 2002). This means that not the entire building 
users are removed from the buildings in a fire event. It is designed to allow the occupants who are at the closest area from a fire to evacuate first while warning the others who are not at immediate risk to stand by. The occupants outside the risk floor are then evacuated if it is necessary to do so. This strategy can reduce the congestion on the routes of escape and thus decrease the evacuation time.

The specific design features for the use of phased evacuation in high-rise buildings include (Littlefield, 2021):

- Staircases protected by fire resistance lobbies or corridors;

- Compartment floors;

- Automatic sprinkler system installed for buildings over 30 meters in height;

- Fire alarm system with provision of voice communications system.

\subsubsection{Relocation or Defend-in-place}

The traditional evacuation method for high-rise buildings is the combination of relocation and defend-in-place. Defend-in-place is used for a portion of the phased strategy and applies to occupants on floors other than the fire origin floor and the two floors below and above the fire floor (Tubbs and Meacham, 2008). Defend-in-place strategy might be more suitable in residential buildings or health care facilities such as hospitals and care units, where some of the building users especially patients are mobility-challenged (Tubbs and Meacham, 2008). For example, it is difficult for patients who need to rely on lifesustaining equipment to escape from hospitals during fire event (Harrington, 2005). The patients' condition may be adversely affected when escaping from the building. This strategy allows the occupants to stay put while the fire fighters first extinguish the fire. If the fire could not be controlled, then a full evacuation would be started.

\subsection{Factors to Consider in Employing Evacuation Strategies for High-rise Buildings}

The decision to evacuate or not in an emergency in managed buildings mostly lie with the building or facilities managers (Craighead, 2014; New South Wales Government, 2016). There is, however, prior decision making on the nature of evacuation strategy suitable for a certain building use. Several factors play a role in the determination of a suitable evacuation strategy for various building use types. Some of these factors include occupant characteristics, building characteristics, fire safety features, reliable emergency response service, evacuation exercise (Craighead, 2009; Craighead, 2014; Proulx and Pineau, 1996; Tubbs and Meacham, 2007).

\subsubsection{Occupant Characteristics}

Normally office building users are expected to better understand emergency instructions compared to other buildings users (Solomon, 2008). Occupants' knowledge on emergency procedures such as evacuation procedures, evacuation plan, roles and responsibility in an emergency, is an important factor in evacuation strategies (Proulx, 2001). Occupancy capacity is another factor to consider when deciding an evacuation strategy in high-rise buildings (Tubbs and Meacham, 2007). Occupancy capacity is used for sizing the vertical escape route. It is considered suitable for high-rise building where phased evacuation is employed (Parker and Wood, 2013). Another key characteristic in the physical condition of the occupants. Occupants with mobility problems, visual, auditory, and even intellectual impairment present additional challenges and require special attention during evacuations (Ronchi and Nilsson, 2013; Craighead, 2014; Proulx, 2002).

\subsubsection{Building Characteristics/Fire Safety Features}

The type of building, whether it is low-rise building or high-rise building, or purpose group such as institutional, office, shop, or residential, can affect the evacuation strategies during a fire event (Ronchi and Nilsson, 2013. Mohd Adnan and Daud (2010) argues that building features which include fire safety features varies based on the type of building and the activities of its tenants. According to New South Wales Government (2016) high-rise buildings never are designed for total evacuation due to the inability of all the building occupants to evacuate at once from the building. Phased evacuation is mostly appropriate. The building characteristics in term of design, such as the size and width of staircases, the width of doors exits, and the area of refuge floors, can affect the evacuation possibilities (Proulx and Pineau, 1996). In Malaysia, the building design characteristics are almost similar as stated by Proulx and Pineau (1996) but there is no specific regulation regarding the refuge area of the highrise buildings. 
Fire safety features in a building is another factor to consider toward the deployment of suitable evacuation strategies. Fire detection systems such as sprinkler system and smoke detectors function to detect and suppress fire. Communication systems, detection systems and suppression systems need to be provided at every floor of the building especially the evacuation zone (Tubbs and Meacham, 2008).

\subsubsection{Reliable Emergency Response Services}

Building management team determines the evacuation strategies (Craighead, 2014) and is responsible for life safety procedures (Fire Services Act 1988, 2006; Fire Services Regulations 2001, 2001). The building management team's responsibilities include:

- Maintaining the building's life safety components and fire safety system;

- Maintaining the Emergency Operations Plan;

- $\quad$ Providing fire safety training to staff to perform the duty of floor warden;

- Conducting fire drill with Fire Rescue Department.

As part of the emergency response team, the floor warden is designated among the building users of each floor of the buildings (Proulx and Pineau, 1996). It is recommended to have at least two floor wardens on each floor to facilitate evacuation. The floor warden needs to respond immediately once the existence of risk in the building is established. Evacuation training for floor wardens is thus important. The emergency response teams need to receive adequate evacuation training on evacuation procedures.

\subsubsection{Evacuation Exercise}

Evacuation exercise is one of the ways to evaluate the efficiency and effectiveness of the evacuation plan and fire safety management in high-rise buildings. Evacuation exercise provide the opportunity for occupants to get used to escape routes, fire safety facilities and the evacuation procedure (Jones and Demers, 2001). According to the International Fire Code 2015, high-rise building evacuations need to be organized annually with all the building occupants in participation (International Code Council, 2016). In Malaysia, the building management team of high-rise buildings need to have a fire drill or evacuation drill at least twice per year in order to provide exposure to fire safety teams on all aspects of rescue in the event of a real fire. It is important to promote the awareness of building occupants to behave correctly in the event of a fire.

\section{METHODS}

A case study approach was used in this study. Literature review to identify aspects of evacuation strategies employed in high-rise buildings and factors responsible for decision making in the choice of evacuation strategies was followed by a case study evaluation of four (4) selected case studies in Kuala Lumpur. A case study was considered an appropriate approach as the study required an examination of actual emergency planning and response practices as well as factors influencing decision making in the adoption of evacuation strategies in high-rise office buildings. According to Yin (2009), a case study approach is appropriate when conducting an in-depth investigating about a phenomenon in its real-life context. A multiple-case case study was utilized as this offers far more strong, reliable and robust analytical conclusions (Yin, 2003; Baxter and Jack, 2008). All the identified case study buildings met the definition of a high-rise building. Basic criteria for selecting the case study high-rise buildings was how accessible they were to enable data collection. The intention of the study was not to draw a comparison among case studies but understand emergency planning and response and identify factors influencing decision making in the adoption of evacuation strategies in high-rise office buildings. Walk-through observations were performed to identify physical characteristics and set-up of the case studies with regards to emergency planning and response. Evacuation exercise reports of the selected case studies were further analyzed to determine the typical emergency scenarios, evacuation strategies employed, and the performance of the evacuation exercise. To determine the factors influencing decision making, interviews were conducted with facility/building managers of the case study buildings who oversee fire safety management at the respective case studies. The interviewees had a minimum working experience of 5 years with expertise in business continuity and emergency preparedness. The objective was to validate factors identified from literature in the context of the selected case studies. The interviewees were further required to rank the factors most vital to their decision making in selecting evacuation strategies on a Likert scale of 1 to 5 (1=least important; $5=$ most important). 


\section{CASE STUDY}

\subsection{Case Study Description}

\subsubsection{Characteristics of the Case Study Buildings}

Table 1 describes the characteristics of the case study buildings. The tallest building among the case studies has 88 floors while the least tall is made up of 18 floors. All buildings are predominantly office purpose buildings with Building A incorporating a shopping complex, Building $\mathrm{B}$ a museum and Building $\mathrm{C}$ a prayer area that could accommodate 600 people

Table 1. Characteristics of the case study buildings

\begin{tabular}{|c|c|c|c|c|}
\hline & Building A & Building B & Building C & Building D \\
\hline Description & Two identical towers & $\begin{array}{l}\text { 50-storey office } \\
\text { tower with the first } \\
\text { two levels a banking } \\
\text { hall and a museum }\end{array}$ & $\begin{array}{l}\text { 38-storey office } \\
\text { tower with, seven } \\
\text { levels of car park, } \\
\text { two levels of services } \\
\text { room and two levels } \\
\text { of banking hall and } \\
\text { prayer hall }\end{array}$ & $\begin{array}{l}\text { 18-storey office } \\
\text { tower. The first three } \\
\text { floors being built } 20 \\
\text { years apart from the } \\
\text { administrative } \\
\text { building }\end{array}$ \\
\hline Height & $452 \mathrm{~m}$ (88 floors) & $244 \mathrm{~m}$ (50 floors) & $152 \mathrm{~m}$ (38 floors) & $77.18 \mathrm{~m}$ (18 floors) a \\
\hline Size & $4,252,000 \mathrm{sqft}$ & $1,800,000 \mathrm{sqft}$ & $4,550 \mathrm{sqft}$ & $4,040 \mathrm{sqft}$ \\
\hline Number of occupants & 11,000 & 6,000 & 1,000 & 2,000 \\
\hline Number of staircases & $\begin{array}{l}8 \text { staircases ( } 4 \text { tower } \\
\text { each) }\end{array}$ & 4 staircases (tower) & 2 staircases & 4 staircases \\
\hline $\begin{array}{l}\text { Number of } \\
\text { lifts/capacities }\end{array}$ & $\begin{array}{l}29 \text { double decker/52 } \\
\text { persons per double } \\
\text { deck car } \\
4 \text { executive/10 } \\
\text { persons per car } \\
6 \text { cargo }\end{array}$ & $\begin{array}{l}\text { Passenger lifts: } \\
\text { G-12 level: } 8 \\
\text { passenger lifts, } \\
\text { 14-25 level: } 6 \\
\text { passenger lifts } \\
26-34 \text { level: } 6 \\
\text { passenger lifts } \\
36-45 \text { level: } 6 \\
\text { passenger lifts } \\
46-51 \text { level: } 4 \\
\text { executive lifts } \\
1 \text { Goods lift } \\
1 \text { Fire Service lift } \\
\text { TOTAL: } 32 \\
\text { Capacity: } 15 \text { people }\end{array}$ & $\begin{array}{l}\text { Passenger lifts: } 12 \text { (4 } \\
\text { lifts per Zone) } \\
\text { Zone A: (11-20 } \\
\text { level), Zone B: (21- } \\
30 \text { level) and Zone } \\
\text { C: (30-38 level). } \\
2 \text { passenger lift at } \\
\text { parking located at } 1 \text { - } \\
10 \text { level. } \\
1 \text { lift Cargo } \\
1 \text { lift executive } \\
\text { (Notes: cargo and } \\
\text { executive lift is } \\
\text { considered as Fire } \\
\text { Service lift) } \\
\text { TOTAL: } 16 \\
\text { Capacity: } 12 \text { people }\end{array}$ & $\begin{array}{l}\text { Passenger lifts: } 3 \text { lifts } \\
1 \text { Cargo lift } \\
1 \text { executive lift } \\
1 \text { BOMBA lift } \\
\text { TOTAL: } 6 \\
\text { Capacity: } 12 \text { people }\end{array}$ \\
\hline $\begin{array}{l}\text { Number of refuge } \\
\text { floors }\end{array}$ & 4 floors & $\begin{array}{l}2 \text { floors located at } \\
\text { Level } 13 \text { and } 35\end{array}$ & None & None \\
\hline Use & $\begin{array}{l}\text { Office, shopping } \\
\text { complex }\end{array}$ & $\begin{array}{l}\text { Office, museum } \\
\text { (opened to public) }\end{array}$ & $\begin{array}{l}\text { Government, } \\
\text { banking, prayer hall }\end{array}$ & Government, office \\
\hline
\end{tabular}




\subsubsection{Fire Safety Management}

\section{Building A}

Emergency Management Team of building A comprise of Crisis Management Team, Incident Commander and its members. The function of Emergency Management Team is to discuss the emergency and to provide manpower and equipment when the emergency level of the building reaches a degree the emergency response team (ERT) of the building itself could not handle. The ERT consisted of a three-man team on fours shifts, 8 a.m. to 2 p.m., 2 p.m. to 8 p.m., 8 p.m. to 2 a.m. and 2 a.m. to 8 a.m., available 24 hours, 7 days a week. They are trained under safety programmes which includes emergency or fire drill, total building evacuation, first aid training, and basic industrial firefighting. Fire drill is organized yearly while total building evacuation, first aid training and basic industrial firefighting training are organized every two years.

\section{Building B}

The enforcement parties of building B include the security department and OSHA committee. The function of OSHA is to keep review and provide corrective measures on the safety and health of the building. For staff management, the emergency response team is known as floor wardens or floor monitors. Floor wardens are trained yearly and rotated to afford every staff the opportunity to have adequate experience. They perform a preventative function as they are given training on the use of firefighting systems such as hose reel and extinguisher. A floor warden represents a department or a floor. This is to ensure that he or she can take care of their own department during the evacuation.

\section{Building $C$}

The emergency response team consist of Emergency Manager, event recorder, evacuation coordinator, incident coordinator, firefighting team, search \& rescue team, building engineer coordinator, security coordinator, and publication and liaison. The meeting of ERT members is held once every three months. The purpose of the meeting is to update occupancy capacity.

\section{Building D}

The building management team of Building D include an emergency response team. The emergency response team consist of emergency manager, event recorder, evacuation officer, incident officer and security officer. The building management team meet annually to review the Standard Operation Procedure. The floor warden of Building D is appointed by tenant of the respective floor. There are two wings of the office space and each wing will have an active and passive floor warden. Evacuation duties are carried out by passive floor wardens during the absence of active floor wardens.

\subsection{Fire Evacuation Strategies}

Building A classifies level of emergency into three (3) tiers: Tier 1 (minor emergency), Tier 2 (major emergency) and Tier 3 (crisis emergency), and employed a 2-stage evacuation strategy: 'stage 1-phased evacuation' and 'stage 2- total building evacuation'. Figure 1, Figure 2, Figure 3 and Figure 4 show the procedures in the 2-stage evacuation strategy.

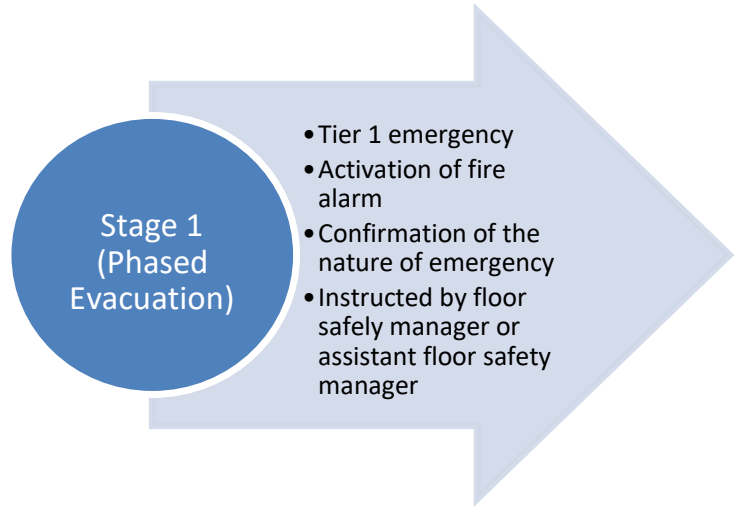

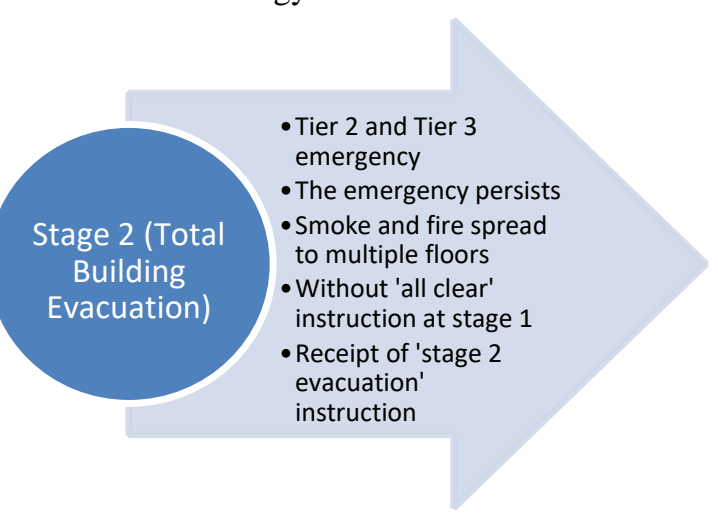

Figure 1. Stage 1: Phased evacuation to Stage 2: Total building evacuation 


\section{Floor of fire origin}

- Occupant of fire floor and single floor above and below:

$\rightarrow$ going down to the temporary refuge floor (three levels below) by using staircase

- Occupants of two floors above the fire floor:

$\rightarrow>>$ salert

Figure 2. Stage 1: Phased evacuation

\section{Low Zone (Level G to 37)}

- Proceed straight down using staircases and exit building

Middle Zone (Level 40 to 60 )

- Use staircases to evacuate to Level $42-\rightarrow$ cross the sky-bridge to the other tower $-\rightarrow$ use shuttle lifts to mezzanine and exit building

\section{High Zone (Level 61 to 77)}

- Use staircases to evacuate to Level $42 \rightarrow$ cross the sky-bridge to the other tower $-\rightarrow$ use shuttle lifts to mezzanine and exit building

Top Zone (Level 78 to 86)

- Similar to High Zone evacuation

Figure 3. Stage 2: Total building evacuation according to zone level (Simultaneous)

\section{Low Zone (Level G to 37)}

- Proceed straight down using staircases and exit building

\section{Middle Zone (Level 40 to 60 )}

- Use staircases to evacuate to Level $42 \rightarrow$ cross the sky-bridge to the other tower $\rightarrow$ use shuttle lifts to mezzanine and exit building

\section{High Zone (Level 61 to 77)}

- Use staircases to evacuate to Level $42 \rightarrow$ cross the sky-bridge to the other tower $\rightarrow>>>$ use shuttle lifts to mezzanine and exit building

Figure 4. Stage 2 Total building evacuation according to zone level (Both towers being affected)

At Building B, the general evacuation strategy usually employed is total building evacuation. However, in the event of earth tremors such as earthquakes, defend-in-place evacuation strategy is to be employed. During interview with the Building Manager, it emerged that the treasury department takes the initiative to practice its business continuity plan. The business continuity department simulates evacuation exercises without the attendance of Fire Rescue Department on a yearly basis with the building management team acting as an observer and providing technical assistance.

At Building $\mathrm{C}$, total building evacuation strategy is employed. It is utilized for all types of emergency situations. The target evacuation time for the occupants to leave the building in compliance with the requirements of the Fire Rescue Department is 42 minutes. The target time is based on the condition of office space and the height of the existing building. When the fire alarm system is triggered, Emergency Manager makes announcement for occupants to evacuate the building and proceed to the assembly area.

Building D also employ total building evacuation for all types of emergencies. Once fire alarm at fire floor is triggered and the fire has been confirmed by floor warden, Emergency Manager will use pre-recorder voice message system to 
alert and instruct occupants to evacuate the building and proceed to the assembly area.

Apart from total building evacuation, phased evacuation exercise is carried out under the request of the building tenant. To clarify, there is a financial department at the ground floor of the building. Due to security and business continuity plan, that department will request to have phased evacuation. Building management team would then assist the tenant to conduct the exercise without the attendance of Fire Rescue Department.

\subsubsection{Evacuation Exercise Reports}

\section{Building A}

In Table 2, the evacuation exercise scenario of Building A for the year 2012 and 2013 is shown, and Figure 5 shows the evacuation reports of the evacuation exercises. Figure 6 illustrates the evacuation process during the evacuation exercises of Building A for the year 2012 and 2013. The results show that actual occupant evacuation times were exceeded on both occasions by 8 minutes in 2012 and 20 minutes in 2013. The feedback from the 2012 evacuation included issues such as:
- need to have more tabletop exercises for the preparedness of the evacuation exercise;

- need to maintain a list of special cases such as disabled persons by the CFCR; and

- fully functioning fire safety systems including smoke management and public address system, however, communication systems needed improvement, especially the walkie-talkie.

Issues related to 2013 evacuation exercise were related to communication and alarm system, headcount system, human behaviour and management issue. Announcement through public address system was unclear, the emergency Headcount Management System (HMS) did not function well. Also, occupants played down the seriousness of the evacuation exercise such as moving too slowly. Management issues involved floor safety managers not playing their roles appropriately.

Table 2. 2012 and 2013 evacuation exercises at Building A

\begin{tabular}{|l|l|l|}
\hline & \multicolumn{1}{|c|}{$\mathbf{2 0 1 2}$} & \multicolumn{1}{c|}{$\mathbf{2 0 1 3}$} \\
\hline Type of Scenario & Fire at Level 30 & Fire at Level 66 \\
\hline Date & $28^{\text {th }}$ February 2012 & $28^{\text {th }}$ October 2013 \\
\hline Type of evacuation strategy employed & Phased evacuation & Phased evacuation \\
& $\begin{array}{l}\text { Total building evacuation } \\
\text { (Low zone levels) }\end{array}$ & $\begin{array}{l}\text { Total building evacuation } \\
\text { (All zone involved) }\end{array}$ \\
\hline Target evacuation time (minutes) & $<60$ & $<60$ \\
\hline Occupant Evacuation Time (minutes) & 68 & 80 \\
\hline
\end{tabular}




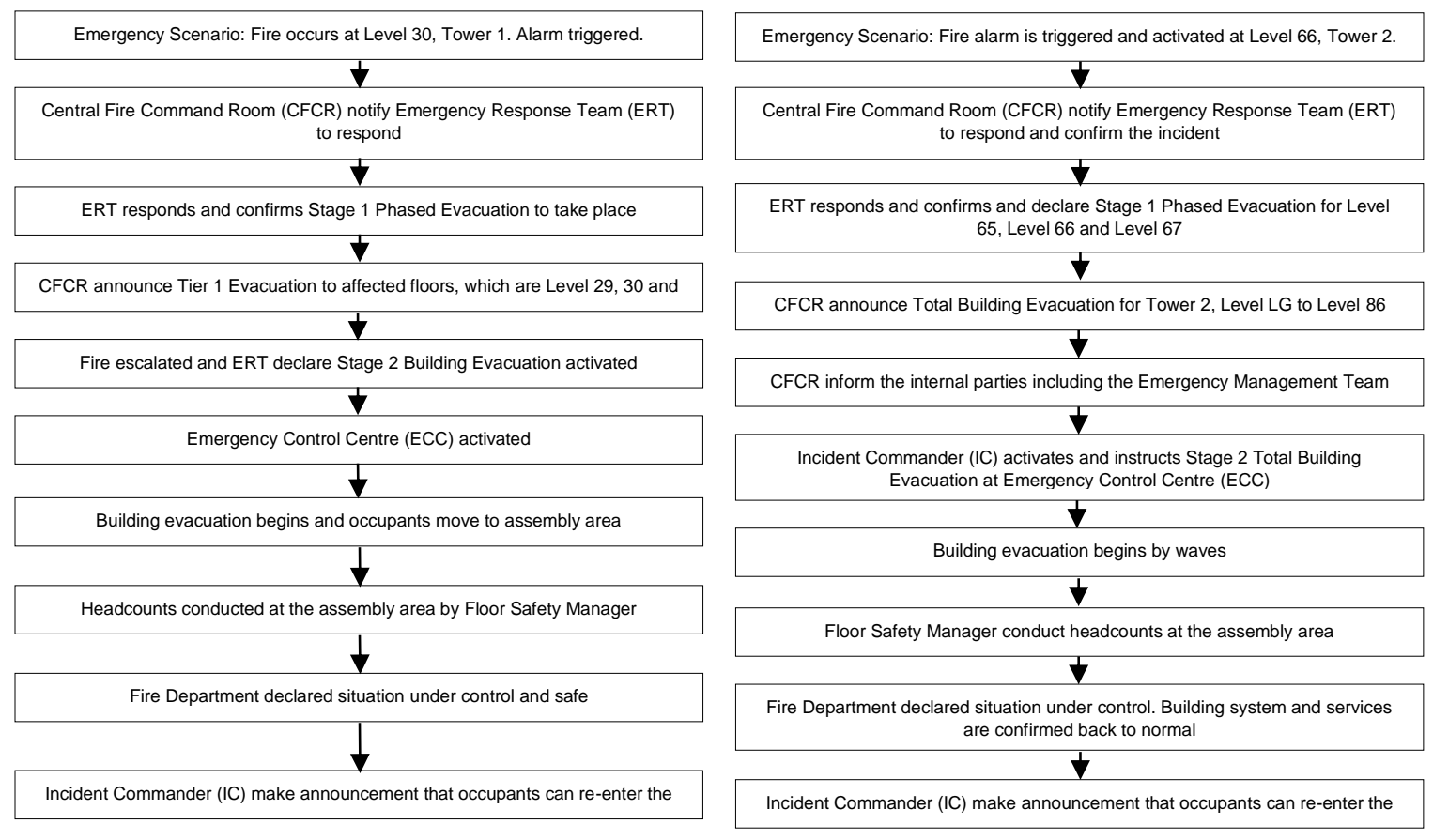

Figure 5. Summary of 2012 (left) and 2013 (right) evacuation exercises of Building A

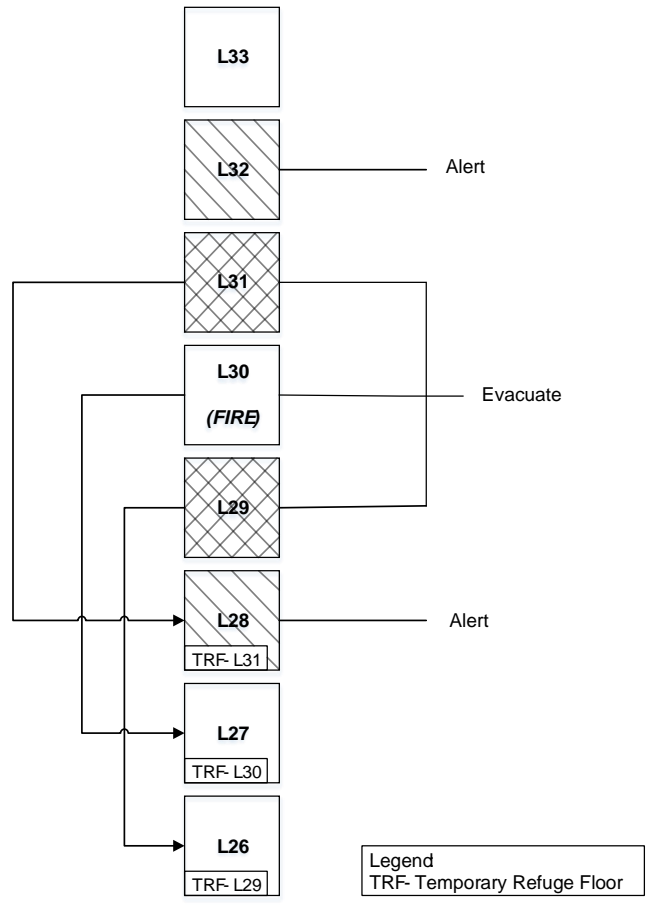

A

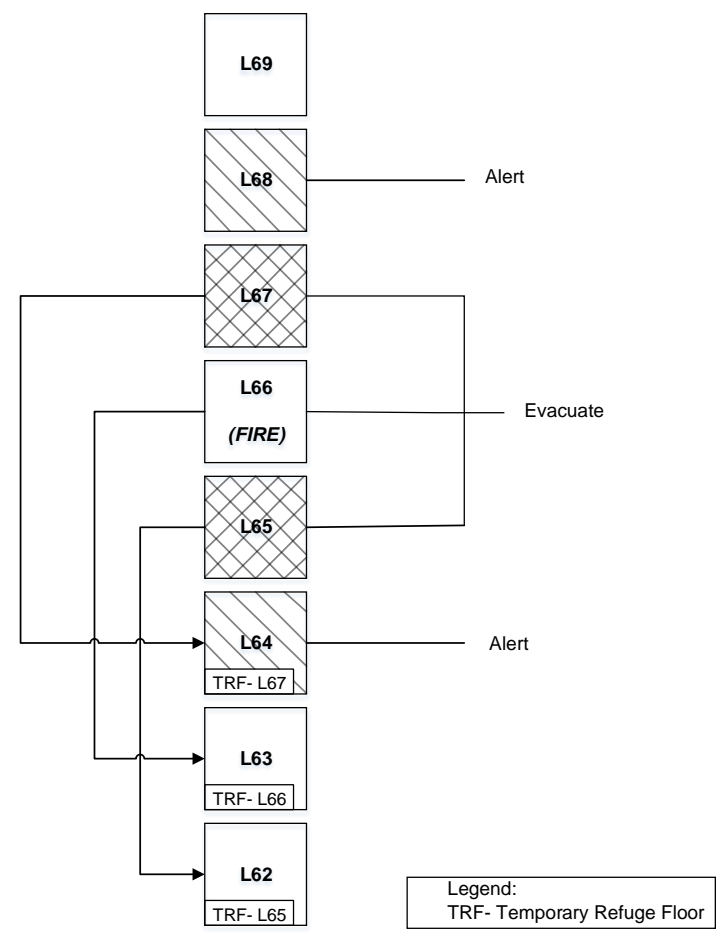

B

Figure 6. A: Floor evacuation for Level 29, Level 30 and Level 31; B: Floor evacuation for Level 65, Level 66 and Level 67 of Building A 


\section{Building B}

Table 3 shows the evacuation exercise scenario of Building B for the year 2011, and Figure 7 shows the evacuation report of the evacuation exercises. The results show that actual occupant evacuation time was exceeded by 3 minutes. Issues related to the evacuation exercise included:

- nonchalant occupant behaviour during evacuation with some occupants exhibiting no sense of urgency.

- inadequate voice communication system with the public-address system available not loud enough to address the huge crowd i.e. issue of audibility and clarity of the public-address system. The farthest point at the assembly area to public address system is about 200 meters and the crowd was about 4,000 people.

- some floor wardens not knowing the appropriate response despite prior briefing.

Table 3. 2011 Evacuation exercise of Building B

\begin{tabular}{|l|l|}
\hline Type of scenario & Fire at level 16 \\
Date & $\mathbf{3 0}^{\text {th }}$ June 2011 \\
Type of evacuation strategy employed & Total building evacuation \\
Target evacuation time (minutes) & 32 \\
Occupant evacuation time (minutes) & 35 \\
\hline
\end{tabular}

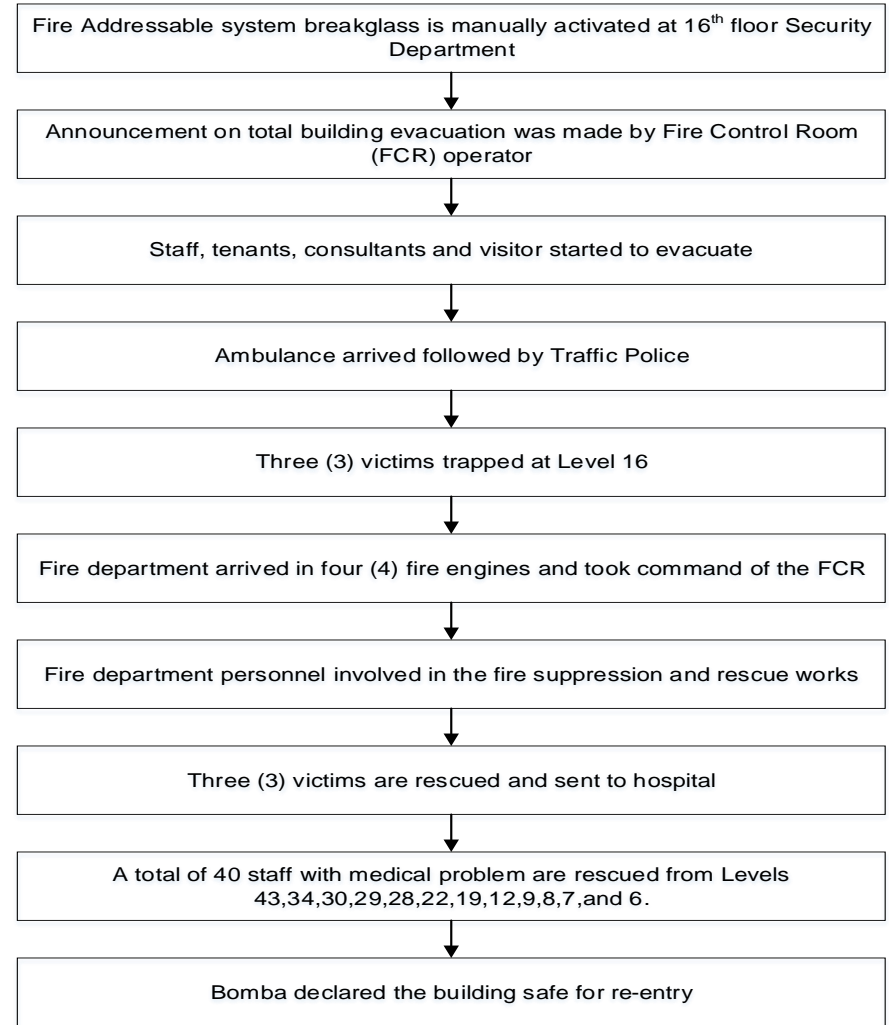

Figure 7. Summary of 2011 evacuation exercise of Building B

\section{Building C}


Preparedness of evacuation exercise had been performed to improve on the evacuation procedure (see Table 4). In Table 5, the evacuation exercise scenario of Building $\mathrm{C}$ for the years 2010 and 2011 is shown, and Figure 8 shows the evacuation reports of the evacuation exercises. The results show that actual occupant evacuation times were bested on both occasions by 7 minutes in 2010 and 2 minutes in 2011 . However, the feedback from the 2010 evacuation exercise reported issues such as incomplete duties of floor warden as some floor wardens did not record the name of floor occupants and failed to control the crowd at assembly area; and lack of seriousness of building occupants as some occupants frolicked during the evacuation process while some hovered in front of building instead of gathering at the assembly area, while incomplete duties of floor warden and emergency response team were the issues from the 2011 evacuation exercise. A floor warden did not submit occupant name list and did not make headcount at assembly area whereas some ERT did not have basic training in the emergency event. While these issues did not affect evacuation times, it can be argued that, a better evacuation time could have been achieved if they were absent.

Table 4. Preparedness of evacuation exercise

\begin{tabular}{|l|l|}
\hline \multicolumn{1}{|c|}{ Date } & \multicolumn{1}{c|}{ Event } \\
\hline April and May 2011 & ERT attended a course on Emergency Preparedness and Response as part of their training \\
\hline July 2011 & $\begin{array}{l}\text { Briefing is given by the Fire Rescue Department to all the floor wardens or representatives of the } \\
\text { floors }\end{array}$ \\
\hline $8^{\text {th }}$ December 2011 & $\begin{array}{l}\text { Discussion about the scenario of the evacuation exercise between the members of ERT and fire } \\
\text { fighters. }\end{array}$ \\
\hline
\end{tabular}

Table 5. 2011 Evacuation exercise of Building C

\begin{tabular}{|l|l|l|}
\hline & $\mathbf{2 0 1 0}$ & $\mathbf{2 0 1 1}$ \\
\hline Type of scenario & Fire at level 24 & Fire at level 14 \\
\hline Date & $30^{\text {th }}$ Jun 2010 & \\
\hline Type of evacuation strategy employed & Total building evacuation & Total building evacuation \\
\hline Target evacuation time (minutes) & 42 & 42 \\
\hline Occupant evacuation time (minutes) & 35 & 40 \\
\hline
\end{tabular}
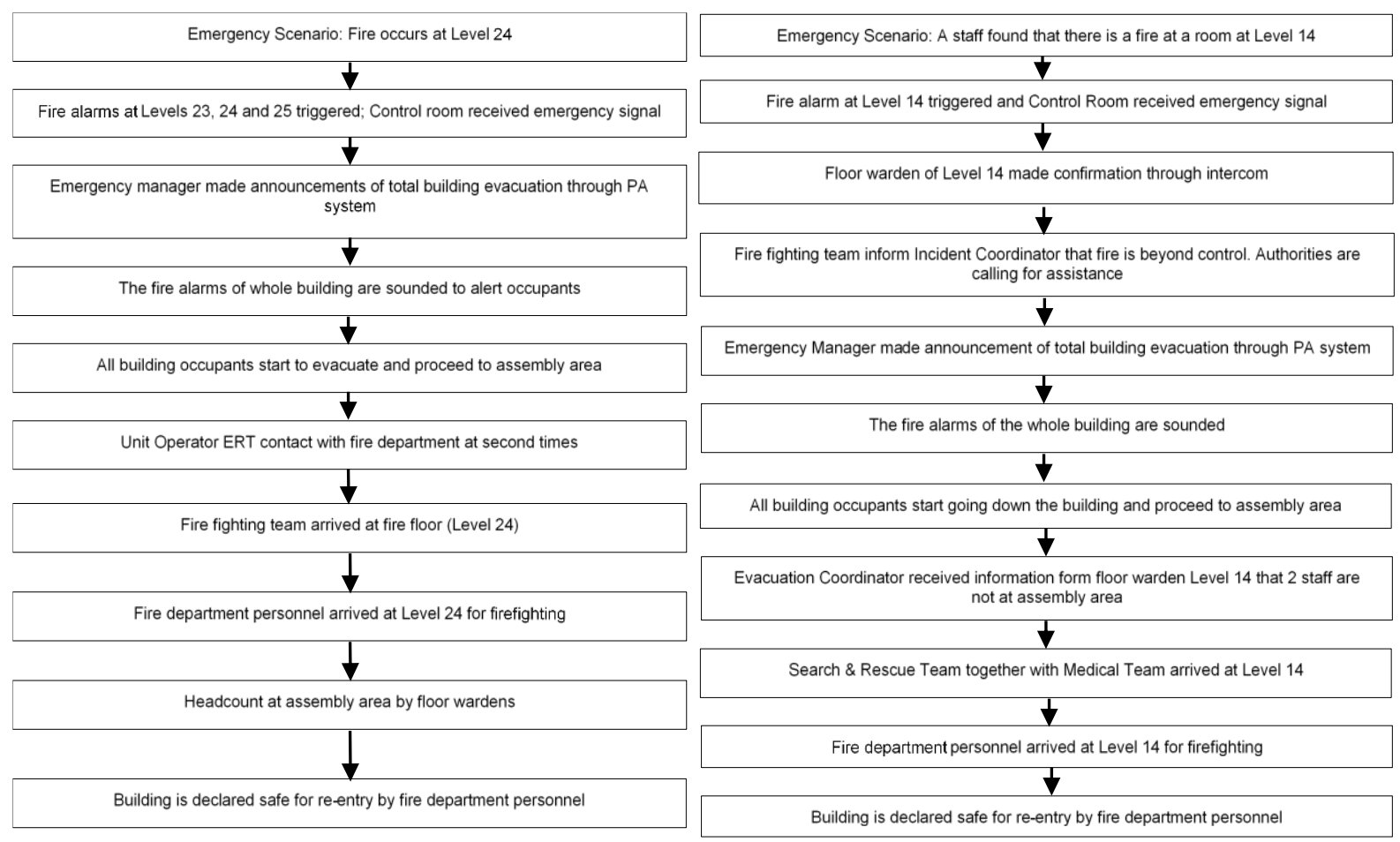
Figure 8. Summary of 2010 and 2011 evacuation exercises of Building C

\section{Building D}

As shown in Table 6, the evacuation took 15 minutes, which was 5 minutes shorter than the target evacuation time of 20 minutes. There was no issue with the 2007 evacuation exercise because fire safety systems functioned properly, and the building management team appropriately executed their responsibilities while the building occupants exhibited absolute cooperation. Summary of evacuation report is shown in Figure 9.

Table 6. 2007 Evacuation exercise of Building D

\begin{tabular}{|l|l|}
\hline Type of scenario & Fire at level 10 \\
\hline Date & $18^{\text {th }}$ December 2007 \\
\hline Type of evacuation strategy employed & Total building evacuation \\
\hline Target evacuation time (minutes) & 20 \\
\hline Occupant evacuation time (minutes) & 15 \\
\hline
\end{tabular}

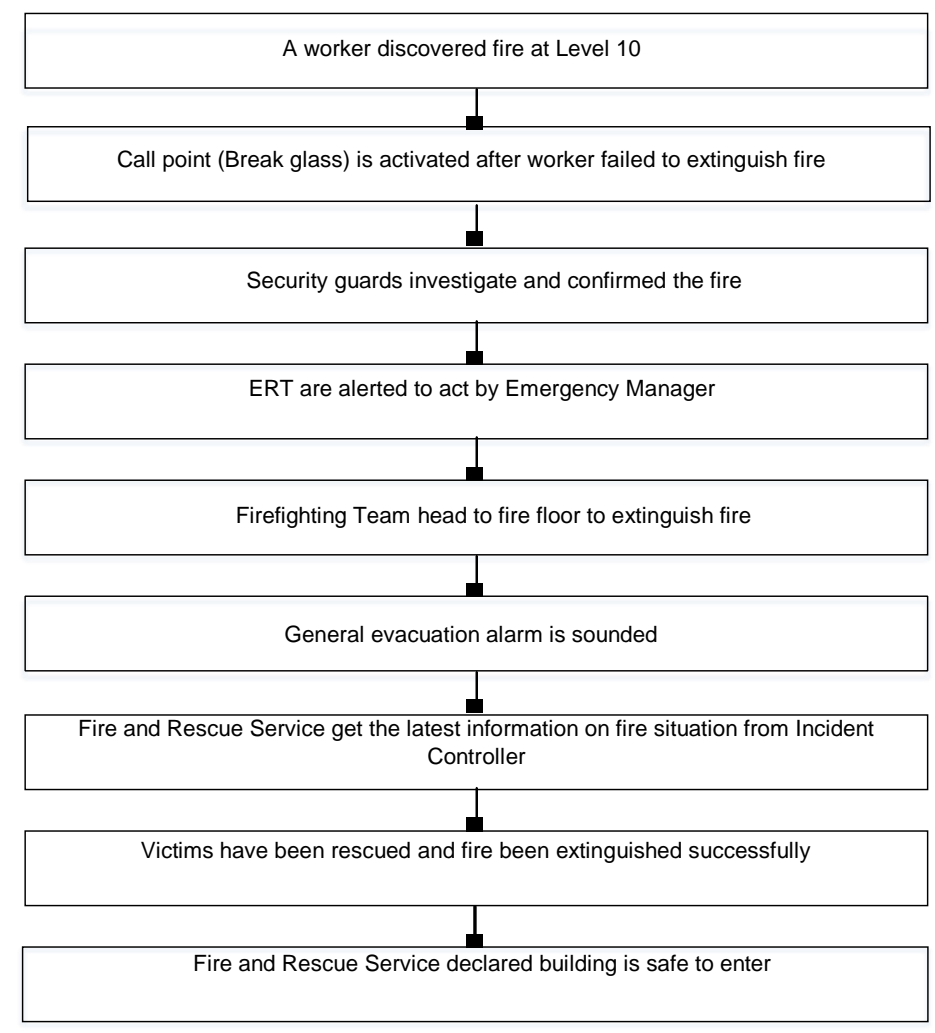

Figure 9. Summary of 2007 evacuation exercise of Building D

\subsection{Decision Making on Evacuation Strategies Employed in High-rise Office Buildings.}

The factors considered in decision making on the choice of evacuation strategies at the case study buildings are discussed in the following subsections.

\subsubsection{Decision Making on Evacuation Strategies Employed in High-rise Office Buildings}

Interview results with facility managers show that different types of building use were given different priorities during evacuation. For instance, as noted by the building manager of Building B, the building occupants who worked in $24 / 7$ high impact security storage, have to 
ensure the place is securely guarded during evacuation exercise, hence, they could not participate in the same evacuation exercise. Building manager of Building D stated that they do practice phased evacuation, but it depended on requests from tenants and it was without the attendance of fire fighters. From this, it can be seen that evacuation strategy depended on the nature of business within the building.

\section{Building Height}

All four (4) case studies employed total building evacuation strategy even though all the buildings under study are more than 75 feet (22.86 meters).

\section{Fire Safety Features}

The fire safety systems at the case study buildings include active fire safety systems, passive safety systems and fire compartmentation as shown in Table 7. All the buildings are installed with L2 alarm system as in BS5839. Furthermore, voice communication systems are used to announce evacuation as well. Building A use, a prerecorded message during phased evacuation and live emergency announcement as and when required. Buildings $\mathrm{B}$ and $\mathrm{C}$ use emergency live announcement while building D use pre-recorded voice messages to make announcements to the building occupants. It was observed that Buildings A, B, C and D are provided with a minimum two (2) staircases as means of escape. Building A, however, utilizes a shuttle lift for evacuation purposes. Besides, sky-bridge evacuation concept is employed at Building $\mathrm{A}$ and it is mainly for phased evacuation purposes. Another key point for phased evacuation or defend-in-place evacuation is the provision of refuge area or refuge floor. Results show that, every floor of Building $\mathrm{A}$ is designated as refuge floor. The refuge area of the other three (3) buildings are located at the pressurized corridor area with the fire rated door protected.

Table 7. Fire safety systems at the case study buildings

\begin{tabular}{|c|c|c|c|}
\hline Building A & Building B & Building C & Building D \\
\hline $\begin{array}{l}\text { Active (smoke detector, heat } \\
\text { detector, automatic sprinkler } \\
\text { system, fireman telephone, } \\
\text { fire alarm, hose reel, wet } \\
\text { riser, fire extinguisher) - } \\
\text { Passive (Firemen switch, } \\
\text { firemen lift, protected } \\
\text { corridor, emergency power } \\
\text { generator, Speaker strobe, } \\
\text { Smoke management } \\
\text { system). } \\
\text { Fire compartmentation } \\
\text { (Pressurization, smoke } \\
\text { exhaust system, dampers). }\end{array}$ & $\begin{array}{l}\text { Active and passive. A } \\
\text { compressive prevention } \\
\text { maintenance system is } \\
\text { done weekly, monthly, } \\
\text { quarterly basis to ensure } \\
\text { all the system are well } \\
\text { maintained. }\end{array}$ & $\begin{array}{l}\text { Sprinklers, wet riser, hose } \\
\text { reel, portable fire } \\
\text { extinguishers, and smoke } \\
\text { detectors. } \\
\text { Triggered sequence of } \\
\text { alarm system is divided } \\
\text { into two (2): } \\
\text { discontinuously followed } \\
\text { by continuously. }\end{array}$ & $\begin{array}{l}\text { Fire alarm system, } \\
\text { fireman's intercom } \\
\text { system, smoke detectors, } \\
\text { fire extinguishers, hose } \\
\text { reels, sprinklers, } \\
\text { emergency lights, fire } \\
\text { rated doors, wet risers and } \\
\text { exit signs. }\end{array}$ \\
\hline
\end{tabular}

\subsubsection{Occupant Characteristics}

\section{Nature and Role of Building User}

The users of high-rise office buildings included occupants and visitors. Usually, building occupants were familiar with the evacuation procedures compared to visitors. Buildings A, C, and $\mathrm{D}$ are multi-tenanted while Building $\mathrm{B}$ is occupied by a single tenant as shown in Table 8 .
Building A consists of office spaces but is also opened to the public. Levels 41 and 42 is the skybridge level and level 86 is observation deck. Three (3) levels are opened to visitors. Building $\mathrm{B}$ has a small museum and it is opened to public also. However, the museum is located at ground floor of the building and therefore, easier to evacuate visitors from the building compared to Building A. 
Table 8. Occupancy characteristic of each building

\begin{tabular}{|c|c|c|}
\hline Building & Occupancy characteristic & Number of occupants \\
\hline A & Multi-tenanted & Approx. 10,000 \\
\hline B & Single-tenanted & Approx. 5000 \\
\hline C & Multi-tenanted & Approx. 920 \\
\hline D & Multi-tenanted & Approx. 800 \\
\hline
\end{tabular}

\subsubsection{Occupant Capacity}

Table 8 shows the number of occupants in each building. Buildings A and B had large amounts of occupants compared to Buildings $\mathrm{C}$ and $\mathrm{D}$. Building A utilized phased evacuation and total building evacuation. Nonetheless, the large number of occupants at Building A caused congestion during evacuation at the sky-bridge and shuttle lift.

\subsubsection{Emergency Reliable Response Services}

\section{Building Management Team}

It emerged that, the building management team of Buildings $\mathrm{A}$ and $\mathrm{D}$ reviewed their standard operating procedures (SOP) yearly. The emergency manager makes the decision whether to carry out defend-in-place, phased evacuation or total building evacuation based on the standard operating procedure. The SOP provides the guideline on preventive maintenance and emergency evacuation and needs to be reviewed before an evacuation exercise. The management of Building B reviewed the SOP 3 times a year due to its nature of business and also under the requirement of OSHA. Building management team of Building $\mathrm{C}$ reviewed it every 15 months together with the maintenance of fire safety systems. This shows that the frequency of reviewing SOP is same as the frequency of maintaining fire safety systems.

\section{Emergency Response Team}

It was found that the floor warden of Building A is known as floor safety manager. The floor safety manager and assistant floor safety manager are appointed for every floor in control of the floor's occupants in the event of an emergency. Building B has 4 floor wardens on each floor, 1 floor warden taking care of each of the 4 departments on each floor. Building $\mathrm{C}$ has maximum 2 floor wardens per floor. Building D has at least 2 floor wardens. The building spaces are divided into 2 wings. According to building manager of Building D, each wing would have a nominated active fire warden and a passive fire warden as a back-up. Although Building D is 18 storeys and is the shortest building among the case studies, it has 4 fire wardens for every floor. This shows that, the number of floor wardens was not necessarily influenced by the height of the building.

\subsubsection{Evacuation Exercise}

\section{Scenario of Evacuation Exercise}

Interview with facility managers revealed that, Building A employed its evacuation strategy based on the level of emergency, while Buildings B, C and D employed their evacuation strategy based on the type of emergency. The four case studies have organized fire drill events. The building management team of Buildings A, B and $\mathrm{C}$ organizes the evacuation drill and fire drill annually. Only Building D organizes the evacuation exercise biennial.

\section{Target Evacuation Time}

Building manager of Building A stated that the building management team will calculate the evacuation time theoretically based on evacuation distance, mobility of occupants, and the exit paths. The target evacuation time of Building $\mathrm{A}$ is less than one hour and for floor evacuation, the time to evacuate from the floor to the temporary refuge floor (TRF) staircase is three (3) minutes. The target occupant evacuation time for Buildings B, $\mathrm{C}$ and $\mathrm{D}$ is 32 minutes, 42 minutes and 19 minutes respectively. Building manager of Building $\mathrm{C}$ pointed that the evacuation exercise was effective if the actual evacuation time was within the target evacuation time. During the evacuation exercises, Building $\mathrm{C}$ and Building $\mathrm{D}$ did not exceed the target evacuation time. On the contrary, Buildings $\mathrm{A}$ and $\mathrm{B}$ exceeded the target evacuation times. The occupant evacuation time of Buildings A in 2012 was 68 minutes and 80 minutes in 2013 evacuation exercise. Both evacuation times exceeded one hour. Meanwhile, 2011 evacuation exercise of Building B was 35 minutes, which exceeded the target evacuation time by 3 minutes. The gap between the real evacuation time and target evacuation time, as noted from the 
evacuation exercises is attributed to behaviour of occupants and failure of fire safety features.

\subsubsection{Factors influencing evacuation strategies employed in high-rise office buildings}

Figure 10 shows the factors influencing the decision making on the choice of evacuation strategies employed at high-rise office buildings ranked in order of importance by the facility managers of the case study buildings.

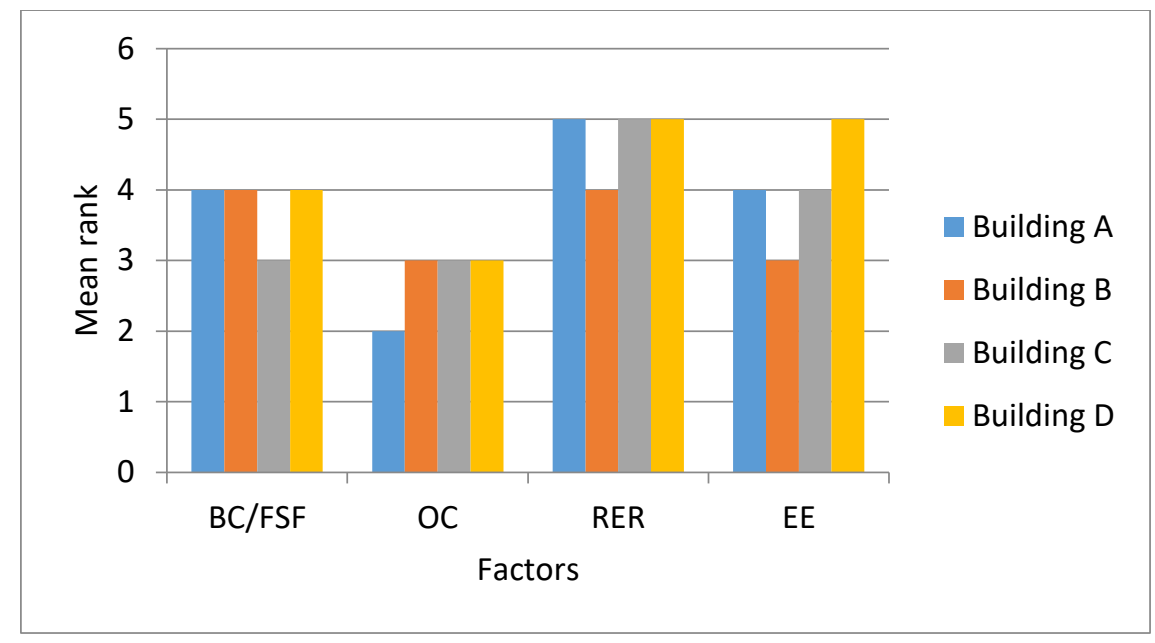

Figure 10. Factors influencing decision making on evacuation strategies employed at each high-rise office building

Reliable emergency response services (RERS) was ranked as the most important factor in an evacuation operation, followed by evacuation exercise (EE), then building characteristics/fire safety features (BC/FSF). The least ranked factor was occupant characteristics (OC). According to the building manager of Building $\mathrm{A}$, there must be appropriate evacuation planning before conducting an evacuation operation. The evacuation planning includes the determination of concept of exercise, building occupants and building systems. Meanwhile, building manager of Buildings $\mathrm{C}$ and $\mathrm{D}$ mentioned that they were more focused on the performance of emergency response teams, because the ERT is the first line of defense or source of assistance before the arrival of authorities such as Fire Rescue Department. Regarding building characteristics, building manager of Building D noted that, means of escape such as pressurized staircase is very important for the occupant evacuation since lift is not to be used for evacuation except if such lif is a designated fire lift. The staircase needs always be free from any obstacles that can block the evacuation route. In contrast, Building A used lift and sky-bridge to evacuate due to the extreme height of the building. On evacuation exercise, building manager of Building A noted that, they designed different scenarios so that the building occupants and emergency response team could familiarize themselves with the evacuation and be able to respond to different emergency situations. The scenarios of exercises of Building A include fire explosion, bomb threat and flammable gas release, while the scenario of exercises of Building $\mathrm{C}$ was more focuses on fire emergencies. Building manager of Building $\mathrm{C}$ expressed similar opinion to building manager of Building A, noting that occupants could be more familiar with the evacuation process if they practiced and are familiar with emergency scenarios.

\section{DISCUSSION}

This paper investigated evacuation strategies in four high-rise office buildings, primarily examining the decision-making process in the adoption of evacuation strategies. It was found that among the four observed high-rise buildings, three employed total evacuation strategy and one employed a two-staged hybrid evacuation (a combination of phased and total evacuation strategy). However, it is expected that defend-inplace and phased evacuation strategy be employed as the most suitable evacuation strategy in high-rise buildings with more than 75 feet above ground level. The findings are in contrast with the position of New South Wales Government (2016) that high-rise buildings are 
unsuitable for total evacuation due to their extreme height factoring in the inability of occupants to effectively evacuate at once.

Regarding decision-making in the adoption of evacuation strategies, emergency reliable response services was identified as the most important factor. The decision to employ an evacuation strategy by building management team could be affected by emergency response team especially on the capability of the firefighting \& search team. This team arrive the fire origin first to extinguish fire before the arrival of fire fighters. If the fire is beyond the control of emergency response team, they would request help from the management team. Following this factor was evacuation exercise. All the observed buildings performed evacuation exercises at least once a year. The nature of evacuation exercises included fire drills and mock emergency evacuations. The scenarios ranged from normal fires to fire explosions, bomb threats, gas release, earth tremors and earthquakes. It is suggested that evacuation exercises be organized at least annually to evaluate the effectiveness of the evacuation plan and evacuation strategies employed in high-rise buildings (Fire Services Regulations 2001, 2001). Regarding the target evacuation time, two of the case studies (Buildings A and B) exceeded the target evacuation time with one of the target evacuation times of Building A exceeded by 33\%. Target evacuation time determines the effectiveness of the evacuation strategies. According to Fire Rescue Department, Malaysia the target evacuation time is based on number of floors per minute. Only one of the buildings had a troublefree evacuation exercise. Though Building $\mathrm{C}$ had an evacuation exercise under the target evacuation time, there were cases of incomplete duties from floor wardens and lack of seriousness from the occupants as they paid little attention to instruction, suggesting that a better job by the floor wardens and cooperation from the occupants could have resulted in an even better evacuation time. Building characteristics/fire safety features, such as nature of the building use, emergency staircases, was the third most important consideration in the decision making for the nature of evacuation strategy to employ. Apart from Building A, which provided a shuttle lift as alternative means of escape due to its extreme height, the remaining observed case study buildings used staircase as a means of escape. It is held that the evacuation time for high-rise buildings using staircase strategy is longer due to disorganized queuing (Aloi and Rogers, 2002), congestion as fire fighters and occupants head towards each other (Chow, 2004), and just the sheer height of these buildings. Traditional means of escape is staircase. People would automatically make use of the staircase in the event of a fire or an emergency. However, it is difficult for highrise building users to evacuate through hundreds of flights of staircases during an emergency. Different people have different physical characteristics, as such, lifts can be used for evacuation where they are specifically designed and designated as fire lifts (Nguyen, Mendis and Fernando, 2019). The decision to provide a shuttle lift and sky-bridge as a means of escape by Building A, therefore, was found to reduce evacuation times by half during fire drills compared to a staircase emergency evacuation. This means of escape as noted by the building manager of Building A is currently the only of its kind in Malaysia. These findings on the most important factors influencing decision making on the adoption of evacuation strategies reflect the positions of Fire Services Act 1988 (2006), Craighead (2009), and Littlefield (2012). Occupant characteristics was the least important factor. All the facility managers expressed a similar opinion, that occupants could be safe to evacuate from the building with the provision of fire safety systems and the assistance of emergency response team and also the occupants' own emergency awareness. This supports Proulx and Pineau (1996) who notes that compared to other building types, office building occupants are expected to have a better understanding of emergency instructions. However, Tubbs and Meacham (2007) emphasized the importance of ensuring the awareness of occupants on emergency procedures, noting occupants' knowledge as an important factor in evacuation strategies. In developing resilient built environment, designers would resort to fire modelling. In fire modelling, designers are basing their approaches on the characteristics of the building and nature of the occupants (Ronchi and Nilsson, 2013). Having occupant characteristics at the bottom of the factors considered in decision making for the adoption of an evacuation strategy suggests differing perspectives of designers and post construction managers. Some of the case study buildings recorded evacuation times higher than target times, and the main issues with the evacuation process were related to occupant behaviour. The fact that occupant characteristics is considered the lowest ranked factor in the decision making for the adoption of an evacuation 
strategy could be attributed to the inability to address and curb nonchalant behaviour from occupants during the evacuation process. The inability to properly manage occupants' movement and poor managerial decision-making during fires have resulted in several fatalities (Chertkoff and Kushigian, 1999; Proulx and Reid, 2006).

\section{CONCLUSION AND RECOMMENDATIONS}

This study evaluated evacuation strategies of identified case study high-rise office buildings in Kuala Lumpur, Malaysia and found that the common evacuation strategy employed was total building evacuation with phased evacuation occasionally practiced. The most important factors in decision making of employing an evacuation strategy were reliable emergency response, followed by building characteristics/fire safety features, then evacuation exercise, with the least factor being occupant characteristics. The argument is that, the adequate provision of reliable emergency response, passive and active fire safety systems, and evacuation exercise routines means that challenges posed by the characteristics of occupants could be overcome. However, it is recommended that facility/building managers and fire safety administrators also pay attention to the behaviour of occupants during evacuation drills and provide more training and motivation to improve their behaviour during evacuation drills. This can be done by making the occupants understand that fire safety training and education is not a burden but a key component of ensuring one's safety and that of others in the event of an emergency.

\section{ACKNOWLEDGEMENTS}

The authors would like to thank Fire and Rescue Department of Malaysia for their support in arranging access to the case studies. The authors gratefully acknowledge the financial support of the University of Malaya Research Grant (grant number: RG180-12SUS; GPF009F-2018) established at the IPPP, University of Malaya.

\section{REFERENCES}

1. Akashah, F., Baaki, T., \& Lee, S. (2017). Fire Risk Assessment of Low Cost High Rise Residential Buildings in Kuala Lumpur: A Case Study. Journal Of Design And Built Environment, , 124139. doi:10.22452/jdbe.sp2017no1.11

2. Aloi, S., \& Rogers, J. (2002). Evacuation \& Life Safety Strategies for Super High Rise Buildings. Norman Disney \& Young: Melbourne.

3. Arliff, A. (2003). Review of Evacuation Procedures for the Petronas Twin Towers, Strategies for Performance in the Aftermath of the World Trade Center. CIB-CTBUH Conference on Tall Buildings. Proceedings. Task Group on Tall Buildings: CIB TG50. CIB Publication(290), 35-42.

4. Australian Building Codes Board. (2013). Lifts Used During Evacuation Handbook. Australia Government and States and Territories of Australia

5. Barney, G. (2002). Vertical transportation in tall buildings. CIBSE National Technical Conference, 12.

6. Baxter, P., \& Jack, S. (2008). Qualitative case study methodology: Study design and implementation for novice researchers. The qualitative report, 13(4), 544-559.

7. Bukowski, R. W. (2007). Emergency Egress Strategies for Buildings. Paper presented at the InterFlam 2007, London.

8. Bukowski, R. W. (2009). Emergency Egress from Buildings. NIST Technical Note 1623. National Institute of Standards and Technology \& U.S. Department of Commerce.

9. Butler, K., Kuligowski, E., Furman, S., \& Peacock, R. (2017). Perspectives of occupants with mobility impairments on evacuation methods for use during fire emergencies. Fire Safety Journal, 91, 955-963.

10. Cheng, C. C. K., Leung, A. Y. T., Lam, K. M., Demirbilek, F. N., \& Williamson, B. J. (2010). A CFD Study of Hong Kong Refuge Floor Design: Floor Height Effect. Engineering Applications of Computational Fluid Mechanics, 4(3), 425-433.

11. Chen, J. J., Wang, X. G., \& Fang, Z. (2016). Collaborative evacuation 
strategy of ultra-tall towers among stairs and elevators. Procedia Eng, 135, 170174.

12. Nguyen, K. T. Q., Mendis, P., \& Fernando, S. (2019). Novel modelling approach for evacuation strategies of tall towers-A case study of Lotus Tower. Journal of Building Engineering, 25, 100763.

13. Chertkoff, J. M., \& Kushigian, R. H. (1999). Don't panic: The psychology of emergency egress and ingress. Westport, CT: Praeger.

14. Chow, W. K. (2004). Aspects of fire safety in ultra highrise buildings. International Journal on Engineering Performance-Based Fire Codes, 6(2), 47-52.

15. Chow, W. K. (2006). Fire safety provisions for supertall buildings. International Journal on Architectural Science, 7(2), 57-60.

16. Chow, W. K. (2012). The need for fire engineering education in Hong Kong. Fire Science and Technology, 31(3), 197-212.

17. Chow, W. K., Fong, N. K., Lui, C. H., Tam, T. K., \& Yue, T. K. (2013). Fire safety strategies for supertall buildings in Hong Kong. CTBUH Journal (1), 131.

18. Craighead, G. (2009). High-Rise Security and Fire Life Safety (3rd ed.). Boston: Butterworth Heinemann.

19. Craighead, G. (2014). Evacuation strategies for high-rise office buildings. Retrieved from http://www.fmlink.com/article.cgi?type $=$ Magazine $\&$ pub $=$ BOMA\&id $=30795 \&$ mode $=$ source

20. CTBUH. (2018). 100 tallest completed buildings in the world by height to architectural top. Retrieved from http://www.skyscrapercenter.com/buildi ngs?list=tallest100-completed

21. Fire Services Act 1988 (Act 341). (2006). Fire Services Act 1988: Incorporating all amendments up to 1 January 2006. Government of Malaysia.

22. Fire Services (Fire Certificate) Regulations 2001. (2001). Fire Services (Fire Certificate) Regulations 2001. Government of Malaysia.

23. Harrington, G. (2005). Emergency preparedness: Evacuation vs. defend-inplace strategies. Retrieved from http://www.facilitiesnet.com/emergency preparedness/article/Emergency-

PreparednessPath-to-Safety-FacilitiesManagement-Emergency-PreparednessFeature--2743

24. International Code Council. (2016). International Fire Code 2015. Retrieved from

http://codes.iccsafe.org/app/book/conte nt/2015\%20San\%20Antonio/2015_IFC _HTML/C hapter\%204.html

25. Jones, J. C., \& Demers, D. P. (2001). Emergency Evacuation Drills. In G. Golonna (Ed.), Introduction to Employee Fire and Life Safety: Developing a Preparedness Plan and Conducting Emergency Evacuation Drills (pp. 9-21): National Fire Protection Association.

26. Lane, B., \& Lamont. S. (2005). Arup Fire's presentation regarding tall buildings and the events of 9/11.Retrieved from http://www.highrisefirefighting.co.uk/d ocs/arup.pdf

27. Lin Y., Fedchenia I., LaBarre B., Tomastik R. (2010) Agent-Based Simulation of Evacuation: An Office Building Case Study. In: Klingsch W., Rogsch C., Schadschneider A., Schreckenberg M. (eds) Pedestrian and Evacuation Dynamics 2008. Springer, Berlin, https://doi.org/10.1007/978-3-64204504-2_30

28. Littlefield, D. (Ed.). (2012). Metric Handbook Planning and Design Data. (3rd ed.). New York: Architectural Press.

29. Mohd Adnan, Y., \& Daud, M. (2010). Factors Influencing Office Building Occupation Decision by Tenants in Kuala Lumpur City Centre - A Delphi Study. Journal of Design and Built Environment, 6(1). Retrieved from https://ejournal.um.edu.my/index.php/jd be/article/view/4983

30. Metropolitan Fire \& Emergency Services Board. (2010). Evacuation of high rise buildings. Community Safety Directorate Guideline, 1-7. Retrieved from http://www.mfb.vic.gov.au/media/docs/ gl-18-v5-r1210-a098a929-fb10-4b519d18-6e072d79ccbb.pdf

31. National Fire Protection Association (NFPA). (2012). Assessment of Total 
Evacuation Systems for Tall Buildings: Literature Review. Available at www.nfpa.org

32. New South Wales Government. (2016). Evacuation Decision Guidelines for Private Health and Residential Care Facilities. New South Wales Government Guidelines. Retrieved https://www.emergency.nsw.gov.au/me dia/277/1117/_/v14zhjewq3nb8k8044/

GuidelineEvacuation-Decision-MakingGuidelines-for-Health-and-Aged-CareFacilities.pdf

33. Nilsson, D., \& Jönsson, A. (2011). Design of evacuation systems for elevator evacuation in high-rise buildings. Journal of Disaster Research. 6(6), 600-609.

34. Nimlyat, P. S., Audu, A. U., Ola-Adisa, E. O., \& Gwatau, D. (2017). An evaluation of fire safety measures in high-rise buildings in Nigeria. Sustainable Cities and Society, 35, 774785.

35. Nizam Husin, H., Khalil, N., Kamaruzzaman, S., Nawawi, A., \& Ismail, F. (2018). Determinant of Attributes and Correlation of Safety Performance via Post Occupancy Evaluation (POE) for Low- Cost Housing. Journal Of Design And Built Environment, 72-86. doi:10.22452/jdbe.sp2018no1.7

36. Proulx, G., \& Pineau, J. (1996). Review of Evacuation Strategies for Occupants with Disabilities (pp 1-20). Ottawa: National Research Council of Canada. Institute for Research in Construction.

37. Ronchi, E., \& Nilsson, D. (2014). Assessment of total evacuation systems for tall buildings. New York: Springer.

38. Ronchi, E., Kuligowski, E. D., Peacock, R. D., \& Reneke, P. A. (2014). A probabilistic approach for the analysis of evacuation movement data. Fire Safety Journal, 63, 69-78.

39. Ronchi, E., \& Nilsson, D. (2013). Fire Evacuation in High-rise Buildings: A Review of Human Behaviour and Modelling Research. Fire Science Reviews,2(1), 7.

40. Huang, L., Chen, T., \& Yuan, H. (2014). Simulation study of evacuation in highrise buildings. Transportation Research Procedia, 2, 518-523.
41. Huo, F., Song, W., Chen, L., Liu, C., \& Liew, K. M. (2016). Experimental study on characteristics of pedestrian evacuation on stairs in a high-rise building. Safety Science, 86, 165-173.

42. Parker, D. \& Wood, A. (2013). (Eds). The Tall Buildings Reference Book. New York: Routledge.

43. Proulx, G. (2002). Understanding Human Behaviour in Stressful Situations. Paper presented at the Workshop to Identify Innovative Research Needs to Foster Improve Fire Safety in the United States, Washington.

44. Proulx, G. (2001). Occupant Behaviour and Evacuation. Paper presented at the 9th International fire Protection Seminar.

45. Proulx, G. (2002). Evacuation Planning for Occupants with Disability. Ottawa, Canada: Fire Risk Management Program, Institute for Research in Construction, National Research Council Canada.

46. Proulx, G., Bénichou, N. (2010).Photoluminescent Stairway Installation for Evacuation in Office Buildings. Fire Technol 46, 471-495. https://doi.org/10.1007/s10694-009$\underline{\text { 0102-z }}$

47. Proulx, G., \& Reid, I. M. (2006). Occupant behavior and evacuation during the Chicago Cook County Administration Building fire. Journal of Fire Protection Engineering, 16(4), 283309.

48. Qu, Y., Gao, Z., Xiao, Y., \& Li, X. (2014). Modeling the pedestrian's movement and simulating evacuation dynamics on stairs. Safety Science, 70, 189-201.

49. Soltanzadeh, A., Alaghmandan, M., \& Soltanzadeh, H. (2018). Performance evaluation of refuge floors in combination with egress components in high-rise buildings. Journal of Building Engineering, 19, 519-529.

50. Solomon, R. E. (2008). Fire Protection Handbook: National Fire Protection Association.

51. Tubbs, J., \& Meacham, B. (2008). Selecting appropriate egress strategies. Consulting-Specifying Engineer, 20-21.

52. Tubbs, J. S., \& Meacham, B. J. (2007). Egress Design Solutions: A Guide to 
Evacuation and Crowd Management Planning. Canada: John Wiley \& Sons.

53. Walls, K. L. (2001). Fire Safety in Buildings. Jurnal Teknologi, 34(1), 1320.

54. Wei, Z. L., Kwok, K. Y., Siu, M. L., \& Zheng, F. (2002). Impact of Floor Planning on Airflow Patterns in Designated Refuge Floor in High-Rise Building. Journal of Architectural Engineering, 8(4), 108-115.

55. Wong, H. L. K., Huo, M. C., Guo, D. G., \& Luo, M. C. (2005). A Refined Concept on Emergency Evacuation by Lifts. Paper presented at the Fire Safety Science-Proceedings of the Eight International Symposium, Hong Kong.

56. Wood, A. (2003). Pavements in the Sky: the skybridge in tall buildings.
Architectural Research Quarterly, 325332.

57. Wood, A., \& Oldfield, P. (2007). Bridging the gap: An analysis of proposed evacuation links at height in the world trade center design competition entries. Architectural Science Review, 173-180.

58. Yin, K. R. (2003). Applications of Case Study Research (2nd ed.). California: Sage Publications.

59. Yin, K. R. (2009). Case Study Research: Design and Methods (Vol. 4th Edition). California: Sage

60. Zhang, X. (2017). Study on rapid evacuation in high-rise buildings. Engineering science and technology, an international journal, 20(3), 1203-1210. 